\title{
AN INVADER AT THE EDGE OF THE WORLD: SPOROBOLUS NEGLECTUS (POACEAE) DISCOVERED AT A REMOTE LOCALITY IN HUNGARY
}

\author{
Gergely KIRÁLY \\ West Hungarian University, Institute of Silviculture and Forest protection \\ H-9400 Sopron, Ady E. u. 5, Hungary; kiraly.gergely@nyme.hu
}

Király, G. (2016): An invader at the edge of the world: Sporobolus neglectus (Poaceae) discovered at a remote locality in Hungary. - Studia bot. hung. 47(2): 335-344.

\begin{abstract}
In 2016, Sporobolus neglectus, a new alien grass species of North American origin has been recognized in Hungary in a particular situation: within a widely isolated part of the Duna-Dráva National Park. The locality is situated S of Vizvár village on the right bank of the Drava River in the territory "Jama", encompassed (excluding the eastern side bordered by Drava) from all directions by Croatian territories. S. neglectus composed a dense stand on 0.2 hectares in a secondary sandy grassland, its dominance is likely supported by the damages caused by wild boar. The establishment of the species in Jama territory is not in accordance with the inundations of the Drava River; also an accidental introduction from the Hungarian mainland seems to be very unlikely. The stand of $S$. neglectus was introduced here probably in connection with wild game feeding made by illegal hunters coming from Croatia. In view of the locality near Vízvár, the species is able to colonize barren sandy surfaces in mass; accordingly, it is a potential invader in the dry sandy grasslands of Hungary, especially in the neighbouring Belsö-Somogy region.
\end{abstract}

Key words: alien species, invasion, national park, pathways, secondary habitats

\section{INTRODUCTION}

The checklist of non-native species in Hungary has considerably been widened in the last decades. The invasion of successful adventives was connected to processes like motorway or railway constructions and transport (e.g. DANCZA and KirÁly 2000, MESTERHÁZY 2005, BÁTORI et al. 2012), trade and irresponsible planting of aquatic plants (e.g. KirÁly et al. 2008, LuKÁcs et al. 2016), agricultural management and trade of various crops (e.g. CsIKY et al. 2004, PARTOSFALVi et al. 2008, MESTERHÁZy and KirÁLY 2013), furthermore to the use of ornamental plants or fruits (e.g. JAKAB et al. 2010, KiRÁLY et al. 2014). Some autochorous or anemochorous pioneers were established also spontaneously (e.g. KirÁLY 2005, MÉsZÁros 2009). In most cases the aliens occurred in predictable habitats and localities, and their spreading was simultaneous also in other countries of Central Europe. 
Sporobolus (dropseed) is a species-rich, nearly cosmopolitan grass genus, represented in Hungary by four alien species (KIRÁLY and HoHLA 2015). In 2016 a further awaited species, S. neglectus Nash has been recognized in Hungary under curious conditions: in a widely isolated, protected part of the Duna-Dráva National Park. This correspondence reports on this new occurrence, its habitat conditions, and possible origin.

\section{MATERIAL AND METHODS}

The field study was conducted along the Drava River in 2016; the author also had several preliminary floristic excursions in the region on both sides of Drava in Hungary and Croatia from 2004 onwards. The coordinates of the recorded localities were determined using a Garmin GPSMAP 64 device. Quadrant number is given according to the Central European Flora Mapping System (NikLFELD 1971). Herbarium acronyms used in the text follow THIERS (2016); voucher specimens are deposited in BP and LI, and in the private herbarium of the author. The topographical classification of Hungary is considered according to DövÉNYI (2010). Nomenclature of plant names follows KIrÁly (2009). The specimens of Sporobolus neglectus were identified using the keys and descriptions of Marković (1973), MELZer (2003), Jogan (2007), and Fischer et al. (2008). In the course of landscape-historical investigations free available maps and aerial photographs were used from http://fentrol.hu, http://mapire.eu/hu/ and http://erdoterkep.nebih.gov.hu homepages.

\section{RESULTS}

The study species

The grass genus Sporobolus involves two species native to the Mediterranean territories, furthermore two invaders (S. neglectus and S. vaginiflorus (Torr.) Wood.), and several casual aliens in Europe (Alegro et al. 2003, Melzer 1994, 2003). From the representatives of the genus found in Hungary, POLGÁR (1941) reported on three species (S. argutus Kunth, S. elongatus $\mathrm{R}$. Br. and S. subinclusus Phil.) as casuals in the industrial zone of Györ; there had been no more records on their occurrence. S. vaginiflorus has been recently recognized in Hungary; as expected, along the main motorway from Croatia to the Pannonian Basin (KIRÁLY and HoHLa 2015). Sporobolus neglectus is native to the central and Atlantic part of the United States (PETERson et al. 2007). The species was found for the first time in Europe probably in the 1950s in Slovenia (Jogan 2007), but due to con- 
fusions with $S$. vaginiflorus its establishment and spreading (especially in Italy and the former Yugoslavia) is not entirely clear. It was recorded in the vicinity of Zagreb, Croatia in 1970 (MAR Ković 1973), in northern Italy in 1980 (MELzER 1981), in France in 1990 (Prost 1991), in Austria in 1993 (Melzer 1994), and in Switzerland in 1999 (TINNER 2013). In all countries listed here it shows an advancing tendency and it is classified as an invader.

Both Sporobolus neglectus and S. vaginiflorus are unimpressive, morphologically variable species (Peterson et al. 2007, Harms 2015). The first one is distinguishable from the latter by the glabrous lemmas ( $S$. vaginiflorus: strigose), by spikelets $1.5-3.0 \mathrm{~mm}$ long (S. vaginiflorus: $(2.5-) 3.0-6.0 \mathrm{~mm}$ ), and by mature fruits 1.2-1.8 mm long ( $S$. vaginiflorus: longer than $1.8 \mathrm{~mm}$ ) (Fig. 1). The sheet of the uppermost leaf is regularly shorter than the inflorescence (in the case of $S$. vaginiflorus it is often overhung or partly overlapping the inflorescence), but this feature is only observable on fruiting specimens.

\section{Locality and habitat in Hungary}

The nearest published records of Sporobolus neglectus to Hungary are situated in Carinthia (Melzer 1994, 2003), Central Croatia (Marković 1973, Ni kolić 2015), and Northern Slovenia (JogAN 2001). It was also expected that this species has already reached Hungary. Nevertheless, a systematic search in 2013 and 2015 on southwest Hungarian roads (including the motorways of the region) produced no success. Notwithstanding, the species was shortly recorded
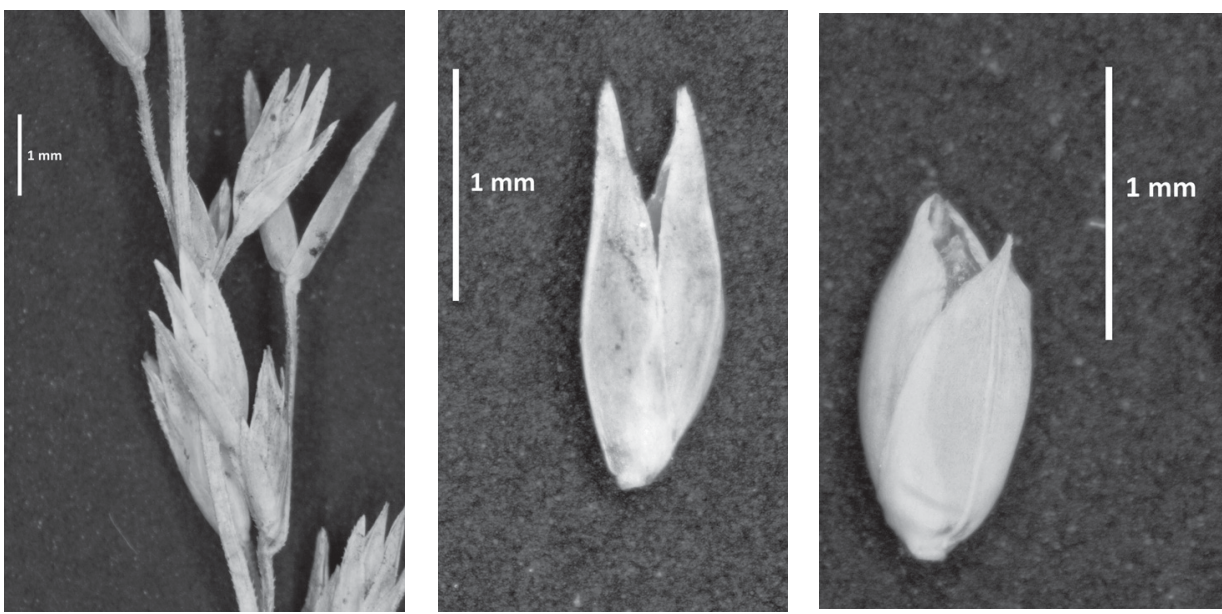

Fig. 1. Sporobolus neglectus Nash: (a) inflorescence part with spikelets of a mature specimen; (b) glumes and (c) single flower with lemma and palea (based on specimens collected in SW Hungary, Vízvár, 28.09.2016, photo V. Tóth). 
in Hungary in the course of the vegetation mapping of protected areas along the Drava River in the southwestern part of the country, but in unusual situation.

Locality data: Dunántúli-dombság (“Transdanubian Hills") macroregion, Somogy County, $2.5 \mathrm{~km} \mathrm{~S}$ of Vízvár village, $46.06393^{\circ} \mathrm{N}, 17.23307^{\circ} \mathrm{E}, 112 \mathrm{~m}$, 9969/1; 28.09.2015, G. Király and S. Csór, BP, LI and herb. Király (Figs 2-3).

The newly discovered locality is lying on the right bank of the Drava River in the district named "Jama". Jama (separated from the Hungarian "mainland") is a projection, $2.3 \mathrm{~km}$ long and $0.4-0.5 \mathrm{~km}$ broad, encompassed (excluding the eastern side bordered by Drava) from all directions by Croatian territory. It is bounded by an old, partly drained and destroyed oxbow with reed and secondary tall herb stands; its higher-lying central part is built of sandy sediments, and covered by degraded forest plantations, and in the western edge by degraded grasslands, respectively (Fig. 4). The entire territory is a specially protected part of the Duna-Dráva National Park, and, in addition, also part of the Natura 2000 network.

Sporobolus neglectus composed in the sandy grassland part of Jama territory a nearly monodominant stand on approx. 0.2 hectares, its dominance was supported here likely by the repetitive damages (creating barren soil surfaces) of wild boar. The species composition of the dry and semi-dry grasslands was similar to those in other degraded sandy habitats in Hungary, with scattered

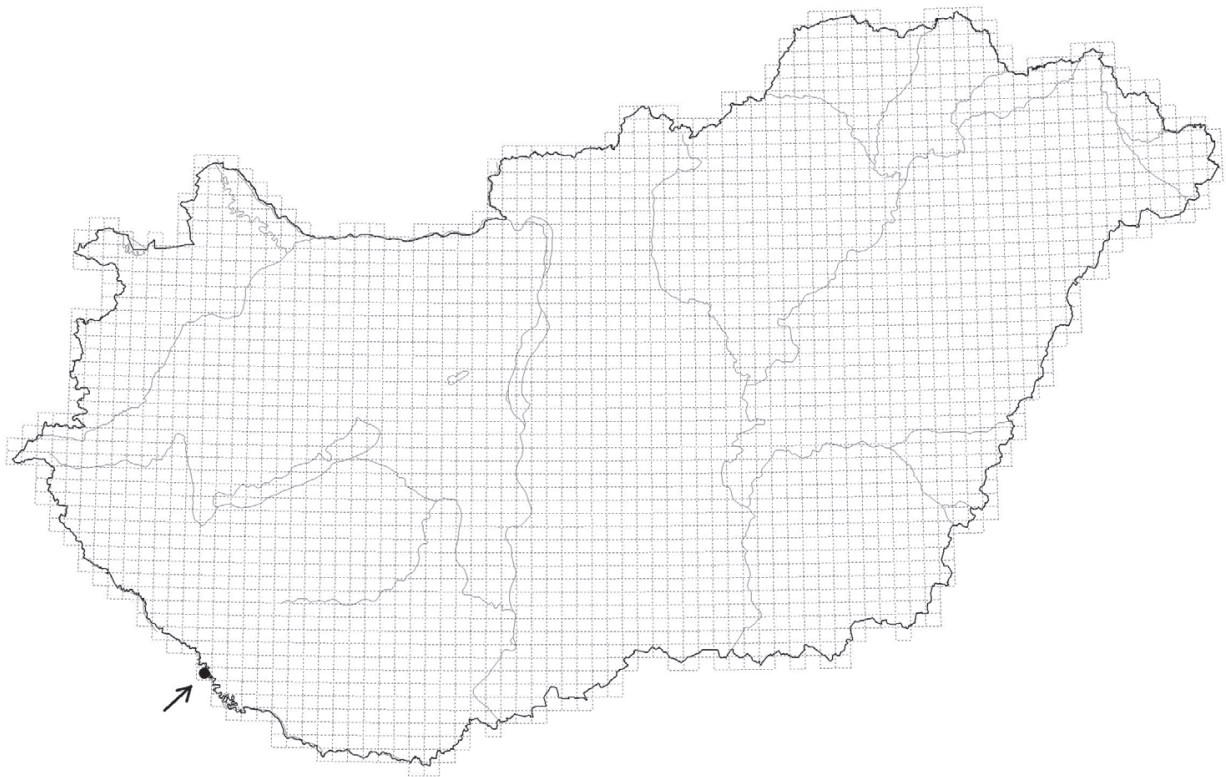

Fig. 2. Distribution map of Sporobolus neglectus Nash in Hungary. 


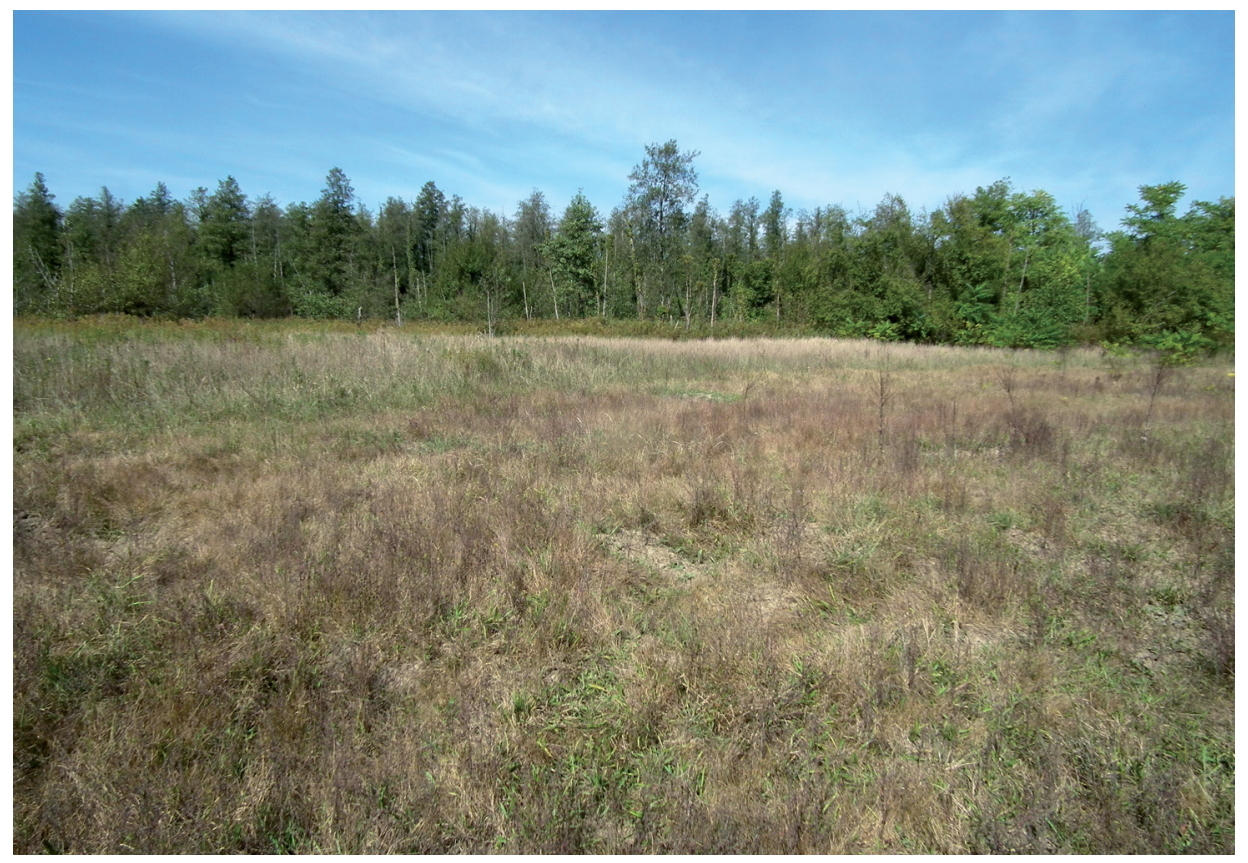

Fig. 3. Habitat of Sporobolus neglectus Nash near Vízvár (Jama) in Hungary: semi-dry secondary grasslands with dense stands of Sporobolus in the foreground, and common alder plantations in the background (28.09.2016, photo G. Király).

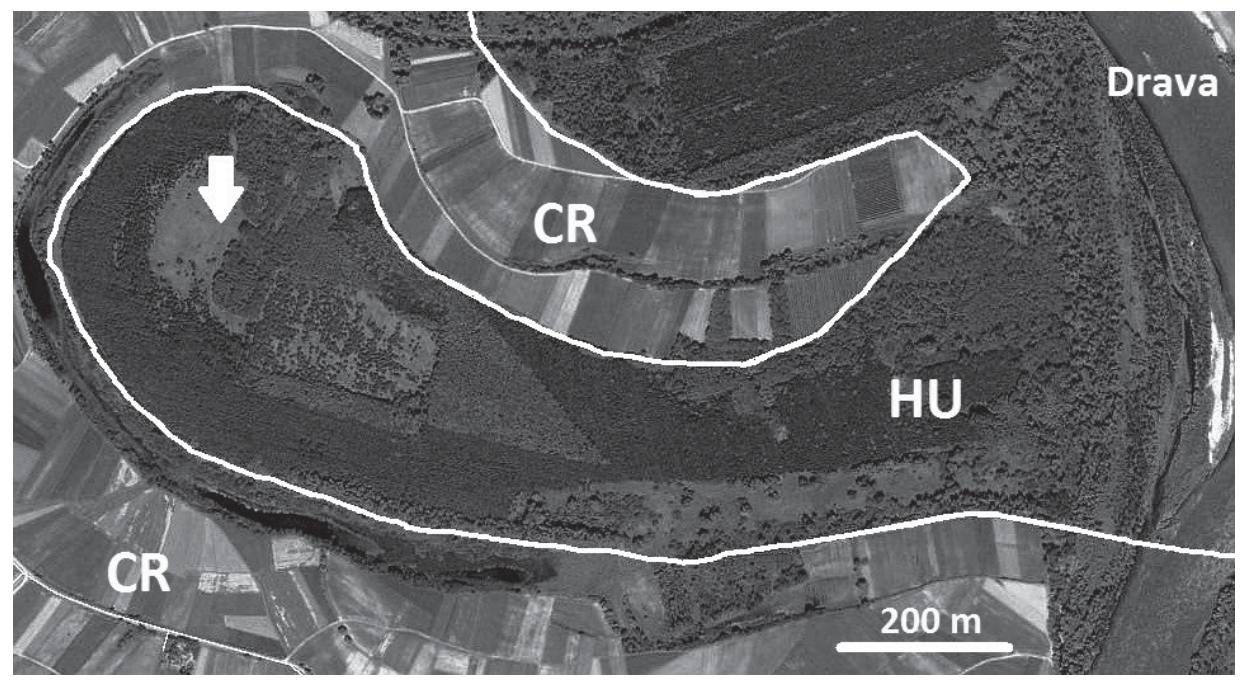

Fig. 4. Schematic map of the Jama district near Vízvár in SW Hungary. Background: Google Map satellite photo, 27.06.2006; $\mathrm{CR}=$ Croatia; $\mathrm{HU}=$ Hungary; the state border is marked with a bold white line, the locality of Sporobolus neglectus is assigned by a white arrow. 
occurrence of native (Bothriochloa ischaemum, Calamagrostis epigeios, Cynodon dactylon, Equisetum ramosissimum, Euphorbia cyparissias, Picris hieracioides, Poa angustifolia, Verbascum lychnitis) and alien (Ambrosia artemisiifolia, Erigeron annuus) disturbance-tolerant species; additionally, few typical representatives of sandy grasslands in the Somogy region (Hieracium cf. rothianum, Tunica saxifraga, Verbascum pulverulentum) were observed as well. Well-preserved nature-like sandy grasslands were not represented in the territory.

\section{Landscape history}

The landscape changes of Jama territory can be reconstructed on the basis of historical maps (source: mapire.eu) and aerial photographs (source: fentrol. hu). Traditionally, the Croatian-Hungarian border was composed by the line of the Drava River (excluding the section of "Répás District"); however, due to the permanently changing watercourse, the boundary line has not been accurately marked for a long time. On the map (section VI.27; 1784) of the First Military Survey the boundary seems to be only approximately mapped. The Second Military Survey (section XXV.63; 1859) shows between Bélavár and Barcs already the same line as recently. Despite the accurate marking of the boundary in the 1850s, the non-regulated watercourse of the Drava River has been changing to the present time, thus there are Hungarian territories (as Jama itself) on the right, and Croatian territories on the left bank of the river. These Hungarian territories became hardly accessible after the WW I.

Jama was in 1859 a treeless agricultural land; later on (1878, during the Third Military Survey) the same with a smaller pasture area (even at the locality - a sandy plateau - of the recent stand of Sporobolus), with few buildings and several smaller roads into the neighbouring Croatian fields. After the WW II, the central part of Jama was covered by cultivated fields; however, a strip along the state border has been abandoned and all accessions to the (at that time) Yugoslavian territories were closed. In the late 1970s the agricultural use was fully abandoned, and the entire area was planted with fast-growing tree species (common alder, black locust, Scotch pine). These plantations also expanded to the uppermost sandy plateaus of Jama, but - as a consequence of the dry soils and the inappropriate selection of the planted species (alder) - the afforestation failed, and a small secondary grassland has been created here. At latest in the 1990s also the forestry management has stopped in Jama, the failed plantation attempts have not been repeated, and the secondary grassland patch is listed recently as forest glade (see: erdoterkep.nebih.gov.hu). The (legal) hunting activity is very low and occasional in the area; both forest plantations and the grassland are highly damaged by big game. 


\section{DISCUSSION}

Sporobolus neglectus was found in Central Europe on sandy or gravelly soils in dry and semi-dry grasslands (MELzer 1981, 1988, MAR KOvić 1973, TinneR 2013, Šilc et al. 2014), most often in ruderal places (industrial areas, roadsides), but also along rivers (on sandy banks). The species was introduced to Europe probably by seeds of North American origin used for greenings and plantations (Melzer 1994, 2003). Melzer also emphasized that there is not about an explosive invasion, only on repeated local establishment from seed material used in lawns. In contrast, several other authors (e.g. TINnER 2013, HOHLA 2014, HoHLA et al. 2015) report on a rapid invasion of the species mainly connected to traffic lines. Probably both types of introduction run in parallel; however, due to the very unimpressive appearance of the species it is often overlooked, and the direction and speed of its invasion is hard to estimate.

In view of the published data of S. neglectus from Croatia (Nikolić 2015) the new Hungarian locality seems to be very isolated in the north. On the other hand, JogAN (2014) referred to a wider occurrence of the species in Croatia, nevertheless, without specific data on its distribution. I have not seen the species during my preliminary floristic studies 2004 onwards in Northern Croatia (neither in the area in the surroundings of the new locality, near Ferdinandovac and Đurdevac), but I did not pay special attention to the secondary grasslands, and the presence of $S$. neglectus cannot be ruled out here.

The establishment of the species in Jama territory is certainly not in accordance with the Drava River as transmitter, because the locality lies $2 \mathrm{~km}$ from the river bank and was not affected by inundations in the last decades. Also an accidental introduction from Hungarian direction is very unlikely because of the lack of agricultural and forestry activities in the area; otherwise, the species has never been reported from Hungary. The grasslands in Jama are explicitly isolated from similar habitats in Croatian territories by the wide belt of the afforestations and oxbow vegetation, thus a spontaneous introduction by zoochory from the neighbourhood is very unlikely. The only plausible way of introduction of $S$. neglectus in Jama is the activity of hunters. We found several feeders and ambushes on the right bank of the river in Hungarian territories, also in and around the grassland of Jama. These certainly belong to illegal Croatian hunters because the Hungarian ones do not have any fixed facilities in the right bank due to the complicated access. Therefore the stand of $S$. neglectus established here probably connected to wild game feeding, and the species occupied later the entire area of the open soil surfaces (caused by the damage of wild boar). Knowing of the considerable coverage of the species, this event could happen several years before. 
Express nature conservational threats caused by $S$. neglectus have not yet been reported in the region; however, more authors analyzed its hypothetical threats. Already MAR Ković (1973) mentioned its possible invasion in riverside grasslands, Tinner (2013) consulted on possible negative effects of S. neglectus to the native pioneer plant communities. Based on the locality near Vízvár, the species is able to colonize barren sandy surfaces in mass; accordingly, it is a potential invader in the extensive grasslands of Hungary (especially in the neighbouring Belsö-Somogy region). However, the (potential but undesirable) expansion of $S$. neglectus certainly will not proceed from the very isolated stand south of the Drava River - it probably will proceed linked to roadsides.

Acknowledgements - The study was financially supported by the project "Agrárklíma.2 VKSZ-12-1-2013-0034". The author is thankful to Duna-Dráva National Park Directorate (Pécs), and especially to Sándor Csór and László Fenyősi (both Barcs) for the organization of field excursions in the hardly accessible territories along the Drava River; to Viktória Tóth (Sopron) for her kind help in creation of detail photographs, and to Michael Hohla (Obernberg am Inn) for information on the spreading of the species in Austria.

Összefoglaló: Közép- és Dél-Európa számos régiójában jelezték a Sporobolus (Poaceae) nemzetség két egyéves észak-amerikai fajának előfordulását és terjedését. Közülük a S. vaginiflorus már 2015-ben előkerült Magyarországon az M7 autópálya mellett. Hozzá hasonlóan a S. neglectus hazai megjelenésével is számolni lehetett, amely gyorsan igazolást is nyert: a faj 2016-ban előkerült Vízvártól délre, a Dráva jobb partján fekvő „Jama” nevű, egykori folyóág által körülölelt területrészen. Itt egy másodlagos, fajszegény homoki gyep nyílt részén jelentős borítást ért el.

A dolgozat ismerteti az újonnan megtalált faj határozóbélyegeit, európai terjedésének menetét és feldolgozza az új lelőhely tájtörténetét, keresve a S. neglectus itteni megtelepedésének forrását és okait. A területet a 19. század közepétől szántóként használták, ez a nagyfokú elszigeteltség ellenére (az első világháború után a Jamát körülvevő korábbi belső határ magyar-jugoszláv államhatárrá változott) az 1970-es évekig fennmaradt. Ekkor a mezőgazdasági művelést felhagyták, a területet pedig égerrel, akáccal és erdei fenyővel beerdősítették, ma e másodlagos faállományok uralják. Egyedül (a sikertelen beerdősítést követően) egy száraz homokplatón alakult ki degradált homoki gyep - a S. neglectus éppen itt fordul elő. A Jama az utóbbi évtizedekben gyakorlatilag érintetlen: a Duna-Dráva NP fokozottan védett része, szárazföldön elvileg megközelíthetetlen, erdőgazdálkodás és vadászat szinte nincs a térségben, így a $S$. neglectus megjelenése rejtélyes. A feltételezések szerint a faj illegális (a zöldhatáron át horvát területről érkező személyek által kialakított) vadszóró(k) révén kerülhetett be mégis a területre.

\section{REFERENCES}

Alegro, A. L., Biljaković, M., Bogdanović, S. and Boršić, I. (2003): Sporobolus pungens (Schreber) Kunth (Poaceae), rare and endangered psammophytic plant species in Croatia. Natura Croatica 12: 1-7. 
BÁtori, Z., Erdős, L. and Somlyay, L. (2012): Euphorbia prostrata (Euphorbiaceae), a new alien in the Carpathian Basin. - Acta Bot. Hung. 54: 235-243.

http://dx.doi.org/10.1556/ABot.54.2012.3-4.2

Csiky, J., Király, G., Oláh, E., Pfeiffer, N. and Virók, V. (2004): Panicum dichotomiflorum Michaux., a new element in the Hungarian flora. - Acta Bot. Hung. 46: 137-141. https://doi.org/10.1556/abot.46.2004.1-2.9

DANCZA, I. and KirÁly, G. (2000): A Senecio inaequidens DC. előfordulása Magyarországon. (The occurrence of Senecio inaequidens DC. in Hungary). - Kitaibelia 5: 93-109.

DövÉNYi, Z. (ed.) (2010): Magyarország kistájainak katasztere. (Cadastre of small regions of Hungary). - MTA Földrajztudományi Kutatóintézet, Budapest, 876 pp.

Fischer, M. A., Adler, W. and OswAld, K. (2008): Exkursionsflora für Österreich, Liechtenstein und Südtirol. 3., verbesserte und erweiterte Auflage. - Land Oberösterreich, OÖ Landesmuseen, Linz, 1392 pp.

Harms, R. T. (2015): A survey of the Sporobolus compositus and Sporobolus vaginiflorus complexes (Poaceae) in Texas. - Phytoneuron 49: 1-27.

Нонца, M. (2014): Hystrix patula - neu für Österreich, sowie weitere Beiträge zur Flora von Oberösterreich, Salzburg, Steiermark und Vorarlberg. - Stapfia 101: 83-100.

Hohla, M., Diewald, W. and Király, G. (2015): Limonium gmelini - eine Steppenpflanze an österreichischen Autobahnen sowie weitere Neuigkeiten zur Flora Österreichs. - Stapfia 103: $127-150$.

JakAb, G., NótÁri, K., Csengeri, E. and Horváth, Á. (2010): Az amerikai falgyom (Parietaria pensylvanica Mühlenberg ex Willdenow) Magyarországon. (Occurrence of Parietaria pensylvanica Mühlenberg ex Willdenow in Hungary). - Kitaibelia 15: 87-94.

Jogan, N. (ed.) (2001): Gradivo za Atlasflore Slovenije. [Materials for the Atlas of Flora of Slovenia]. - Center za kartografijo favne in flore, Miklavž na Dravskem polju, $443 \mathrm{pp}$.

Jogan, N. (2007): Poaceae (Gramineae). - In: MARtinčič, A. (ed.): Mala Flora Slovenije, 2nd edition. Tehniška založba Slovenije, Ljubljana, pp. 826-932.

Jogan, N. (2014): Muhlenbergia schreberi J. F. Gmel (Poaceae), a new naturalized species in Croatia. - Acta Bot. Croat. 73: 465-470. https://doi.org/10.2478/botcro-2014-0009

KIRÁly G. (2005) Kiegészítések a magyar adventív-flóra ismeretéhez II. Az Epilobium ciliatum Rafin. Magyarországon. (Distribution and habitats of Epilobium ciliatum Rafin. in Hungary). - Flora Pannonica 3: 27-39.

KIRÁLY, G. (ed.) (2009): Új magyar füvészkönyv. Határozókulcsok. (New Hungarian Herbal. Identification keys). - Aggteleki Nemzeti Park Igazgatóság, Jósvafo, 616 pp.

KirÁly, G. and Hohla, M. (2015): New stage of the invasion: Sporobolus vaginiflorus (Poaceae) reached Hungary. - Studia bot. hung. 46: 149-155. http://dx.doi.org/10.17110/StudBot.2015.46.2.149

KirÁly, G., Bонumil, T. and VoJTĚCH, Ž. (2014): Észrevétlen özönfaj a magyar flórában, az örmény szeder (Rubus armeniacus Focke). (Rubus armeniacus Focke, an unnoticed invader in Hungary). - Kitaibelia 19: 220-228.

KirÁly, G., Steték, D. and BÁNYÁsz, Á. (2008): Spread of invasive macrophytes in Hungary. Neobiota 7: 123-131.

LukÁcs, B. A., Mesterházy, A., Vidéki, R. and KirÁly, G. (2016): Alien aquatic vascular plants in Hungary (Pannonian ecoregion): Historical aspects, data set and trends. - Plant Biosystems 150: 388-395. http://dx.doi.org/10.1080/11263504.2014.987846

MAR ković, L. (1973): Sporobolus neglectus Nash, nova adventivna vrsta Jugoslavije. (Sporobolus neglectus Nash, a new alien species in the flora of Yugoslavia). - Acta Bot. Croat. 32: 237-242. 
Melzer, H. (1981): Neues zur Flora von Kärnten und dem angrenzenden Süden. - Carinthia II 171/91: 103-114.

Melzer, H. (1988): Über Eragrostis frankii C. A. Meyer ex Steudel, Polygonum pensylvanicum L. und weitere Pflanzenfunde in Friaul-Julisch Venetien (Italien). - Linzer biol. Beitr. 20: 771-777.

Melzer, H. (1994): Sporobolus neglectus Nash, ein neues Gras in der Flora Österreichs, und Funde weiterer bemerkenswerter Blütenpflanzen in Kärnten. - Carinthia II 184/104: 499-513.

Melzer, H. (2003): Sporobolus vaginiflorus (Poaceae), ein Neubürger aus Nordamerika, lange übersehen in Österreich - und anderes Neue zur Flora von Kärnten. - Neilreichia 2-3: 131-142.

MesterháZy, A. (2005): Geranium purpureum Vill. előfordulása Magyarországon. (The occurrence of Geranium purpureum Vill. in Hungary). - Kitaibelia 11: 65.

Mesterházy, A. and KirÁLy, G. (2013): Az óriás muhar (Setaria faberi Herrmann) előfordulása Magyarországon. (The occurrence of Setaria faberi Herrmann in Hungary). - Kitaibelia 18: 136-141.

MÉszÁros, A. L. (2009): A Symphyotrichum ciliatum (Ledeb.) G. L. Nesom felbukkanása Magyarországon. (The occurrence of Symphyotrichum ciliatum (Ledeb.) G. L. Nesom in Hungary). - Kitaibelia 14: 86-88.

Niklfeld, H. (1971): Bericht über die Kartierung der Flora Mitteleuropas. - Taxon 20: 545-571. http://dx.doi.org/10.2307/1218258

Nikolić, T. (ed.) (2015): Sporobolus neglectus Nash in Croatia. - Flora Croatica Database (http:// hirc.botanic.hr/fcd). Faculty of Science, University of Zagreb (accessed on 2016/10/10).

Partosfalvi, P., Madarász, J. and Dancza, I. (2008): Az ázsiai gyapjúfü (Eriochloa villosa (Thunb.) Kunth) megjelenése Magyarországon. (The occurrence of Eriochloa villosa (Thunb.) Kunth Herrmann in Hungary). - Növényvédelem 44: 297-304.

Peterson, P. M., Hatch, S. L. and Weakley, A. S. (2007): Sporobolus R. Br. - In: Barkworth, M. E., Anderton, L. A., Capels, K. M., Long, S. and Piep, M. B. (eds): Manual of grasses for North America. Intermountain Herbarium and Utah State University Press, Logan, Utah, pp. 212-217.

PolgÁr, S. (1941): Győrmegye flórája. (Flora Comitatus Jaurinensis). - Bot. Közlem. 38: 201-352.

Prost, J.-F. (1991): Une graminee nouvelle dans L'Aine. - Le Monde des Plantes 84/442: 30.

ŠILC, U., KošıR, P., BALANT, M. and Glasnović, P. (2014): Antropogene rastlinske združbe na območju Luke Koper. (Anthropogeneous plant communities in the Port of Koper). - Hladnikia 34: 45-51.

ThIERs, B. M. (2016): Index Herbariorum: A global directory of public herbaria and associated staff. - New York Botanical Garden's Virtual Herbarium, http://sweetgum.nybg.org/ih/ (accessed on 30 September 2016)

Tinner, U. (2013): Zwei neue Grasarten im St. Galler Rheintal: Sporobolus vaginiflorus und Sporobolus neglectus. - Baubinia 24: 53-56.

(submitted: 12.10.2016, accepted 10.11.2016) 